DOI https://doi.org/10.30525/978-9934-588-80-8-2.23

\title{
СУЧАСНИЙ НАУКОВИЙ ДИСКУРС КРІЗЬ ПРИЗМУ НОВИХ СТРАТЕГІЙ ПІЗНАННЯ СВІТУ
}

\author{
Сагач Г. М. \\ доктор педагогічних наук, \\ професор кафедри методики викладання $i$ змісту освіти \\ КЗВО «Одеська академія неперервної освіти Одеської обласної ради»

\section{Букач М. М.} \\ доктор педагогічних наук, \\ професор кафедри освітньої політики \\ КЗВО «Одеська академія неперервної освіти Одеської обласної ради» \\ Левчишена О. М. \\ кандидат історичних наук, \\ проректор з науково-методичної роботи \\ КЗВО «Одеська академія неперервної освіти Одеської обласної ради» \\ м. Одеса, Україна
}

Метою роботи є аналіз сучасного наукового дискурсу в системі культури крізь призму нових стратегій пізнання світу, наукового стилю мислення учених різних сфер, які актуалізуються у XXI ст. із його Апокаліптичними викликами загрози життю Планети Земля, існуванню людства. Філософський супровід проблеми філософії науки та освіти розглядають Г. Гейзенберг [2], С. Кримський[3], I. Пригожин, I. Стенгерс [4], К. Пряженцева [5], I. Еткінс [6], В.Торосян [7] та ін.

На стику епох увиразнюються різні стандарти раціональності, різноманітні інтелектуальні цілі науки. Виникла трагічна «колізія між цивілізацією та екзистенцією» [3, с.419], коли увиразнилася загроза безодні, хаосу, дегуманізації життя, пріоритету прагматичних, матеріальних інтересів перед духовно-моральними цінностями. Відомий французький мислитель Анрі Мальро заявив, що XXI ст. або буде століттям духовності, або його зовсім не буде. Тому актуалізувалася проблема нового мислення, адекватного новим проблемам духовної модернізації суспільства «свідків Чорнобильської пожежі» [3, с. 354], вимога осмисленості життя, «святості буття» (А. Швейцер), благоговіння перед усім живим, тому що світ можна образно уявити, як «всесвітній ковчег» (Гуссерль), де протистояння смерті відбувається через Культуру з новою ноосферною ідеологією людства у вимірах пріоритету духовного над матеріальним, коеволюції природи і людини, 
осмисленою відповідальністю особистості перед усім існуючим, усвідомленням спорідненості людської, тваринної, планетарноекологічної систем ноосфери. До ХХ ст. класичним ідеалом пізнання був автономний розвиток науки, який мав лінійний, кумулятивний характер, а нині розвивається як нелінійний, некумулятивний [7, с. 5]. Сучасні учені говорять про ноосферу як «моноліт планети, життя, інстинкту та духу» [3, с. 638].

Апокаліптичний конфлікт людини і природи породжує згасання космічних процесів самоорганізації живої матерії, бо ліміти людського свавілля у природі мають свої межі. Науковий дискурс кінця XX ст. початку XXI ст. активізував розуміння науки, як «феномен цивілізації» [3], із варіантним мисленням, яке оперує множинністю рішень проблемних ситуацій, пошуком комплементарності, доповнювальності можливих сценаріїв подій, де пізнання може привести до успіху і до поразки із катастрофічними наслідками, бо «наука - раціональна форма духовної діяльності» [7, с. 9].

Французький математик Р.Том аналізує пізнавальний процес у термінах «теорій катастроф», описує його як боротьбу з неозначеним результатом, де шанси виграшу менші за шанси програшу. Актуалізувалася інтелектуальна проблема синтезу досягнень різних наук - розвитку нових стратегій наукового пізнання, де долається «асиметрія протиставлення єдиної істини множині помилок завдяки припущенню багатоликості істинного результату, його конституювання через множину думок(гадок)» [3, с. 641].

Класична кібернетика розвивала концепцію «універсального інтелекту», яка зазнала кризи, тому замість неї висунуто концепцію множини можливих моделей мислення в рамках теорії фреймів, семантичних сіток, концептуальних структур мови тощо. Природознавство у новоєвропейському розумінні починалося з коперниканської революції, покінчило 3 антропоцентризмом, конституюється через уведення причинної матриці аналізу фізичної реальності із власним механізмом дії. Актуалізувалися наукові напрями квантової фізики із квантовомеханічним описом фізичної реальності, введенням систем відліку спостерігача в релятивістській механіці. Г. Гейзенберг писав у цьому контексті: «У природознавстві предметом дослідження $є$ вже не природа сама собою, а природа, що підлягає людському запитанню» [2, с. 301].

Фізик I. Прихожин аналізує «експериментальний діалог», де об'єкт не може бути пізнаний «сторонніми очима», бо потребує підключення дослідника як розпізнавальної системи до пізнаваного буття [4]. Синергетичні дослідження концепції «експериментального діалогу» людини з природою засвідчують нову стратегію пізнання, як стратегію співучасті компонентів єдиного процесу, що самоорганізується. 90 
Людина виступає у функції об'єктивної розпізнавальної системи чи як інструментально діючий чинник. Антропний принцип буття розглядає людину «репрезентантом, представником творчих можливостей Універсуму» [3]. Сучасна наукова картина світу розглядає людину, яка універсалізується, з боку того, що вона робить, а світ конкретизується, як те, що творить саму людину з ії творчими можливостями.

Учення В.I. Вернадського про ноосферу виявляє коеволюцію людини та природи в діяльнісному аспекті. Різні науки, зокрема, кібернетика, інформатика, синергетика, соціобіологія, інтенсивно розвиваються в рамках аналогії функціонування природних та штучних систем людської діяльності. Інтенсивно розвиваються науки про людську діяльність: ергономіка, праксеологія, логіка дій, соціологія праці, соціальна психологія, педагогічна та політична риторика, філософське вчення про практику. Розвиваються комплексні наукові напрямки за схемою людської діяльності: математична економіка, теорія оптимального планування, структурна лінгвістика, космічна медицина. Людська діяльність виявилася аналогічною та плідною в математиці: теорія операцій, теорія раціональних дій, теорія рішень, теорія гри, алгебра конфліктів, теорія алгоритмів, теорія конструктивної математики.

Синергетика розвивається аналогічно до людської діяльності, де порядок у системах, що самоорганізуються, досягається не на сталості, а за рахунок змін, спонтанності, свободи - спонтанної програмності. В ембріології відоме морфо-генетичне поле, у складних системах виникає аналог душі, чим заповнюється прірва між суб'єктивним об'єктивним [4].

Наукове пізнання кінця XX-початку XXI ст. характеризується актуалізацією «стратегії співучасті» - підключення суб'єкта до системи об'єктів, перетворення людської діяльності в умову реалізації можливостей конституювання фрагментів предметної сфери пізнання у фізичні об'єкти. Це зближує інженерну та наукову діяльність, пізнання та гру як арсенал різних можливостей. Розвивається модельно-гральний підхід у розвиткові наукової картини світу з розвитком комп'ютерної техніки як машинно-людських систем. Приклад - програма гри «Життя» Джона Конуея в рамках «теорії клітинних автоматів» [6].

Науковці різних країн активно розробляють машинно-людські системи 3 кооперативним, сумісним мисленням, що створюе процеси інтелектуалізації цивілізації, іiї самомоделювання. Приклад - потужний колайдер лабораторії ЦЕРН у Швейцарії $з$ його лякаючими пошуками «часточки Бога», що може мати непередбачувані для людства і Планети Земля наслідки. Показовим $є$ ефект машинно-людських систем інтелекту, отриманий як «чинник диявола» в обчислювальному експерименті в Інституті загальної фізики РАН у 1992 р., про що пише С.Б. Кримський, 
як про феномен «введення злого духу», зовнішнього стохастизатора при порушенні законів статистичної механіки при дослідженні плазми в закритому посуді [3]. Загострюється проблема наукової етики у духовноморальному вимірі: святий апостол Павел попереджає, що багато чого існую цікавого, але не все те є корисним людині [1].

Множаться приклади моделювання парадоксів сучасної наукової картини світу - про семіотичну онтологію пізнання через феномен інформаціології, зокрема, в інформаційному аспекті природи. Розвиток квантової фізики у вивченні квантових закономірностей світу актуалізував проблему семіозису природних об'єктів: «треки», «каскади», «плями» тощо як знакові сліди у камері Вільсона. Зближення фізики, біології, математики, генної інженерії тощо породило розшифрування кодів генетичної інформації людини, як мікрокосму у макрокосмі[6].

Філософія та лінгвістика вивчають феномен поширення лінгвістичної парадигми гуманітарних наук на всепізнання в цілому - це лінгвістичний поворот у методології науки [6]. Науковці відзначають перехід від аналізу суб'єкт-об'єктної взаємодії до знаково-символічного моделювання реальності.

Отже, у сучасному науковому дискурсі 3'явився новий режим пізнавальної діяльності, евристична сила ідей у полілінійності, поліваріантності, комунікативній артикуляції з ознаками «гуманітарної революції» на межі тисячоліть із розумінням єдності усіх форм живого на Землі та їі планетарного буття із відповідальністю людини за життя.

Нова ноосферна ідеологія людства, внутрішня логіка науки породжена новим почуттям глобальності, спорідненості людської, тваринної, планетарно-екологічної систем ноосфери. Це актуалізує проблему духовно-моральної культури науковців, ролі наукової етики в системі людина - природа, життя -смерть, буття - небуття, добро - зло, тимчасове - вічне. Це вивищує роль духовно-морального виховання підростаючого покоління в системі освіти в умовах викликів XXI ст., коли визрівають умови для розвитку нових наукових уявлень про світ i Всесвіт, а «точкою біфуркації» виступає перебудова основ науки через відбір найцінніших світоглядних філософем, відповідних викликами нової епохи, де пізнання - трансценденція софійності, а нова раціональність - утвердження духовності [3].

Українські вчені, зокрема Кримський С.Б., відстоюють «нову етику солідарності» перед загрозою небуття, у відстоюванні коеволюції людини і природи, як «світову гармонію» (А. Енштейн), де світ - це текст Бога. Тому від людства очікується мегасинтез Історії, Духу, Творчості на основі софійного принципу життя в Істині. 


\title{
Література:
}

1. Біблія або Книги Святого Письма Старого й Нового Заповіту. Українське Біблійне Товариство, К., 2003. 1375 с.

2. Гейзенберг Г. Шаги за горизонт. - М., 1987. 301 с.

3. Кримський С.Б. Під сигнатурою Софії. - К.: Видавничий дім «Києво-Могилянська академія», 2008. 718 с.

4. Пригожин И., Стенгерс И. Порядок из хаоса. - М., 1989. 290 с.

5. Пряженцева К. Лінгвістичний поворот у філософії. - АКД, К., 2000. $340 \mathrm{c}$.

6. Эткинс И. Порядок и беспорядок в природе. - М.,1987. 324 с.

7. Торосян В.Г.Эволюция стиля мышления в исследованиях Вселенной (от древнейших времён до конца XX в.): Автореф. дис. ... докт. филос. н., Ереван, 1989. 42 с.

DOI https://doi.org/10.30525/978-9934-588-80-8-2.24

\section{ACTUALITY OF THE HUMANITARIAN DIRECTION OF PHILOSOPHY OF MODERN EDUCATION}

\author{
Sakun A. V. \\ Doctor of Philosophy, Associate Professor, \\ Head at the Department of Philosophy, \\ Political Science and Ukrainian Studies \\ Kyiv National University of Technology and Design \\ Kadlubovich T. I. \\ Candidate of Political Science, Associate Professor, \\ Senior Lecturer at the Department of Philosophy, \\ Political Science and Ukrainian Studies \\ Kyiv National University of Technology and Design \\ Chernyak D. S. \\ Candidate of Sociological Sciences, Associate Professor, \\ Senior Lecturer at the Department of Philosophy, \\ Political Science and Ukrainian Studies \\ Kyiv National University of Technology and Design \\ Kyiv, Ukraine
}

The education of post-industrial society, Ukrainian and world, seeks new paradigms for the formation of the information age. The processes of virtualization, digitalization, the incredible pace of development of digital 